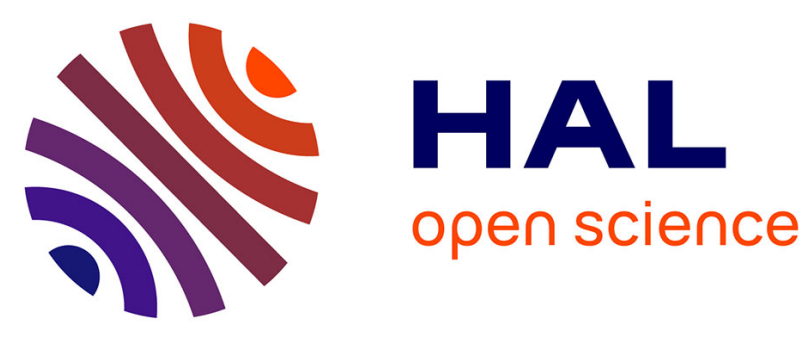

\title{
Multiproxy evidence of 'Little Ice Age' palaeoenvironmental changes in a peat bog from northern Poland
}

François de Vleeschouwer, Natalia Piotrowska, Jaroslaw Sikorski, Jacek Pawlyta, Andriy Cheburkin, Gaël Le Roux, Mariusz Lamentowicz, Nathalie Fagel, Dmitri Mauquoy

\section{To cite this version:}

François de Vleeschouwer, Natalia Piotrowska, Jaroslaw Sikorski, Jacek Pawlyta, Andriy Cheburkin, et al.. Multiproxy evidence of 'Little Ice Age' palaeoenvironmental changes in a peat bog from northern Poland. The Holocene, 2009, vol. 19, pp. 625-637. 10.1177/0959683609104027 . hal-00987445

\section{HAL Id: hal-00987445 https://hal.science/hal-00987445}

Submitted on 6 May 2014

HAL is a multi-disciplinary open access archive for the deposit and dissemination of scientific research documents, whether they are published or not. The documents may come from teaching and research institutions in France or abroad, or from public or private research centers.
L'archive ouverte pluridisciplinaire $\mathbf{H A L}$, est destinée au dépôt et à la diffusion de documents scientifiques de niveau recherche, publiés ou non, émanant des établissements d'enseignement et de recherche français ou étrangers, des laboratoires publics ou privés. 


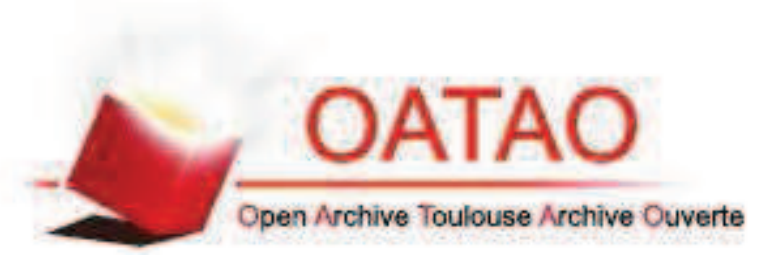

\section{Open Archive TOULOUSE Archive Ouverte (OATAO)}

OATAO is an open access repository that collects the work of Toulouse researchers and makes it freely available over the web where possible.

This is an author-deposited version published in : http://oatao.univ-toulouse.fr/ Eprints ID : 11496

To link to this article : DOI : 10.1177/0959683609104027

URL : $\underline{\text { http://dx.doi.org/10.1177/0959683609104027 }}$

To cite this version : De Vleeschouwer, François and Piotrowska, Natalia and Sikorski, Jaroslaw and Pawlyta, Jacek and Cheburkin, Andriy and Le Roux, Gaël and Lamentowicz, Mariusz and Fagel, Nathalie and Mauquoy, Dmitri Multiproxy evidence of 'Little Ice Age' palaeoenvironmental changes in a peat bog from northern Poland. (2009) Holocene, vol. 19 (n 4). pp. 625-637. ISSN $\underline{0959-}$ $\underline{6836}$

Any correspondance concerning this service should be sent to the repository administrator: staff-oatao@,listes-diff.inp-toulouse.fr 


\title{
Multiproxy evidence of 'Little Ice Age' palaeoenvironmental changes in a peat bog from northern Poland
}

\author{
François De Vleeschouwer, ${ }^{1,2 *}$ Natalia Piotrowska, ${ }^{2}$ Jarosław \\ Sikorski, ${ }^{2}$ Jacek Pawlyta, ${ }^{2}$ Andriy Cheburkin, ${ }^{3}$ Gaël Le Roux, ${ }^{1}$ \\ Mariusz Lamentowicz, ${ }^{4}$ Nathalie Fagel ${ }^{1}$ and Dmitri Mauquoy ${ }^{5}$
}

\begin{abstract}
('AGEs: Argile, Géochimie et Environment sédimentaires, Geology, Univesity of Liège, Allée du 6 Août, B18, Sart Tilman, B-4000 Liège, Belgium; ${ }^{2}$ Silesian University of Technology, Institute of Physics, Department of Radioisotopes, GADAM Centre of Excellence, Krzywoustego 2, 44-100

Gliwice, Poland; ${ }^{3}$ Institute of Environmental Geochemistry, University of Heidelberg, Im Neuenheimer Feld 236, B-69120 Heidelberg, Germany; ${ }^{4}$ Department of Biogeography and Palaeoecology, Institute of Palaeogeography and Geo-ecology, Adam Mickiewicz University, Dzięgielowa 27, 61-680 Poznań, Poland; ${ }^{5}$ Geography \& Environment, School of Geosciences, University of Aberdeen, Elphinstone
\end{abstract} Road, Aberdeen AB24 3UF, UK)

\begin{abstract}
Little Ice Age' (LIA) climatic deteriorations have been abundantly documented in various archives such as ice, lake sediments and peat bog deposits. Palaeoecological analyses of peat samples have identified these climatic deteriorations using a range of techniques, for example palynology, plant macrofossils, testate amoebae or carbon isotopic analyses. The use of inorganic geochemistry and the reconstruction of dust fluxes has remained a challenge in tracing the nature of LIA climatic changes. Although the idea of enhanced erosion conditions and storminess is commonly discussed, the conditions for dust deposition in peatlands over Europe during the LIA are rarely favourable, because the natural forest cover over Europe was much more important than nowadays, preventing dust deposition. This intense forest canopy masks the deposition of dust in peatlands. In northern Poland, near the Baltic shore, the Słowińskie Błota area was deforested around AD 1100, ie, just before the LIA, and therefore constitutes a key area for the reconstruction of LIA climatic change. With the support of a well-constrained chronology, climatic fluctuations are recorded in an ombrotrophic bog using inorganic geochemistry, plant macrofossils and carbon isotopic analyses. The reconstruction of LIA climatic changes is in good agreement with other records from Poland and NE Europe. However, a c. 50-year discrepancy can be observed between various records. This discrepancy is possibly due to progressive time-dependent cooling gradient from north to south Europe.
\end{abstract}

Key words: Peat, multiproxy, 'Little Ice Age', geochemistry, stable isotopes, radiocarbon, lead 210, last millennium, Poland.

\section{Introduction}

Recent studies have demonstrated the potential of ombrotrophic bogs to record past pre-industrial fluctuations of elements during the Holocene (eg, Kylander et al., 2005, 2007). Other studies have assessed the potential of peat bogs to record past climatic fluctuations during the last c. 3000 years using botanical (eg, Mauquoy

*Author for correspondence (e-mail: fdevleeschouwer@gmail.com et al., 2002a; Barber et al., 2003) and palynological (eg, Anshari et al., 2001; Davis et al., 2003; Finsinger et al., 2006) proxies. However, climatic fluctuations during the last millennium have been rarely characterized using inorganic geochemistry (eg, Shotyk et al., 1998; Kylander et al., 2007). In addition, multiproxy analyses of northeastern European peat deposits, which include inorganic geochemistry, are scarce (eg, Lukashev et al., 1974; Twardowska et al., 1999; Vile et al., 2000; Novak et al., 2003; Mihaljevic et al., 2006; Syrovetnik et al., 2007). 


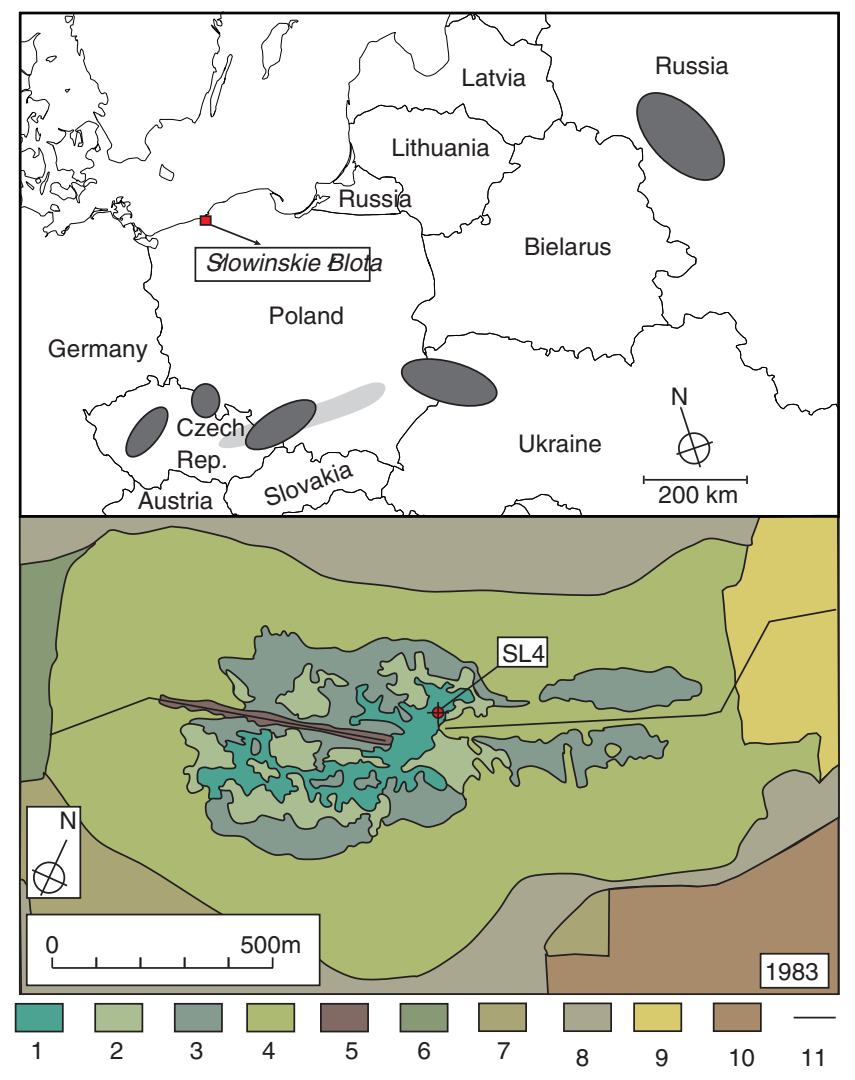

Figure 1 Top. Site location and surrounding eastern European $\mathrm{Pb}$ $\mathrm{Zn}$ ore (light grey) and coal (dark grey) basins (after Bibler et al., 1998; Mukai et al., 2001). Bottom. Peatland preservation indices based on stereoscopic aerial photographs (after Herbichowa, 1998). 1, open peatland complex of Sphagno-tenelli- Rhynchosporetum albae, Sphagnetum magellanici typicum and $<5 \%$ single dwarf pines of c. $2 \mathrm{~m}$ high; 2, open Sphagnetum magellanici pinetosum peatland with more densely ( $\max .10 \%$ ) distributed pines of 2 to $5 \mathrm{~m}$ high; 3 , small patches of open Sphagnetum magellanici pinetosum peatland with initial state of Vaccinio uliginosi-Pinetum, small patches of Sphagnetum magellanici typicum and sparse pine of 4 to $8 \mathrm{~m}$ high; 4 (4+5), $8 \mathrm{~m}$ to $20 \mathrm{~m}$ high pine and birch-pine cover (50\% to $80 \%)$ tree (Vaccinio uliginosi-Pinetum and Betuletum pubescentis); 5, community with Calluna vulgaris on dried peat; 6, degenerated form of alder and young pine forest; 7, meadow and pasture communities (class Molinio-Arrhenatheretea) on humified peat; $8(9+10)$, deciduous forest meadow communities from Molinio-Arrhenatheretea class on mineral soils; 9, initial stage of development of peatland vegetation and young forest planted in remnants of peat exploitation; 10, anthropogenic vegetation (ie, recent); 11, active ditches

The climate of the last millennium is characterized by a warm period known as the 'Medieval Warm Period' (MWP) between c. AD 1000 and 1300. It is followed by a series of climatic deteriorations between $c$. AD 1300 and 1800, the so-called 'Little Ice Age' (LIA). The causes of these climatic deteriorations may be due to changes in solar activity (van Geel et al., 1999; Mauquoy et al., 2004). Cold periods coincide with solar activity minima, as recorded by low sunspot numbers (Stuiver and Braziunas, 1993). During periods of reduced solar activity there is an increased production of ${ }^{14} \mathrm{C}$, as there is less solar magnetic shielding against cosmic rays (van Geel et al., 1999). The $\Delta^{14} \mathrm{C}$ is thus anti-correlated with the number of sunspots. The highest $\Delta{ }^{14} \mathrm{C}$ values are observed during cold periods. Climatic deteriorations during the LIA have been investigated using various archives, for example, ice cores (eg, O’Brien et al., 1995; Dahl-Jensen et al., 1998), lake sediments (eg, Blass et al., 2007; Haltia-Hovi et al., 2007) and peat deposits (eg, Mauquoy et al., 2002a). These climate reconstructions record several periods of climatic deteriorations, namely the Wolf (AD 1300-1380), Spörer (AD 1420-1470) Maunder (AD 1645-1715) and Dalton (AD 1790-1820) minima. However, it remains challenging to attempt tracking these rapid climatic changes using peat inorganic geochemistry, a tool that has been abundantly used to reconstruct past human activities.

Pomeranian Baltic bogs are located on the Southern edge of the cupola-like raised bog area of Europe (Osvald, 1923, 1925; Kulczyński, 1949). Palaeoenvironmental high-resolution multiproxy studies on these mires are very rare in NE Europe. Most of the previous research has focused on past vegetation changes (Wodziczko and Thomaschewski, 1932; Otłuszewski, 1948; Otłuszewski and Borówko, 1954; Szafrański, 1961; Latałowa and Pędziszewska, 2003). The investigation of Herbichowa (1998) provided a Holocene record of local vegetation and basic geochemistry of Słowińskie Błota bog and Staniszewskie bog. In addition, recent investigations using a multiproxy approach are currently in progress (Lamentowicz et al., 2009).

This paper attempts to use the atmospheric soil dust flux (ASD) derived from titanium concentration of a peat record to reconstruct the possible climatic events during the last millennium in northern Poland. Other proxies (carbon stable isotopes and macrofossils) and accurate age dating are also used in order to tentatively picture the various phases characterizing this cold period. Special attention is given to the environmental conditions inferred by the various proxies during the LIA. A comparison with other records from this peat bog and with records over Europe allows us to draw a sketch of the LIA synchroneity over northeast Europe.

\section{Site description}

Słowińskie Błota bog is located $8 \mathrm{~km}$ to the southeast of Darłowo city, and $10 \mathrm{~km}$ away from the Baltic Sea (Figure $1 \mathrm{top}$ ). Up to the end of eighteenth century, Słowińskie Błota bog had been an open bog (ie, not covered by trees). It has been drained twice: (1) in 1880 when surrounding ditches were dug and (2) in 1970 when two ditches were dug through the central part of the bog. The latter were renewed in 1985 (Herbichowa, 1998). The actual vegetation is composed of several species of Sphagnum. In the outer parts, Vaccinium uliginosum, Calluna vulgaris and Betula pubescens are present (Figure 1 bottom).

\section{Methods}

\section{Coring and subsampling}

A $1 \mathrm{~m}$ core (SL4) was retrieved from the central part of the bog (Figure 1 bottom), but away from the 1970 drainage ditches, using a stainless steel $10 \mathrm{~cm} \times 10 \mathrm{~cm}$ Wardenaar corer (Wardenaar, 1986). The core was then wrapped in plastic bags and stored in a fridge. The edges of the core were removed to avoid any metal contamination by the corer. The remaining core was then sliced into $1 \mathrm{~cm}$ thick samples using a titanium knife. Each sample was stored in a plastic bag. In this study, we present various proxies obtained on SL4: macrofossils, inorganic geochemistry, $\delta^{13} \mathrm{C}$, radiocarbon and lead dating. They are compared with selected water-table change indicators from a second core (SL2) retrieved in the same bog, $10 \mathrm{~m}$ away from SL4. SL2 has also been dated and analysed for biological proxies such as pollen, macrofossils and testate amoebae by Lamentowicz et al. (2009).

\section{Chronological control}

${ }^{210} \mathrm{~Pb}$ analyses

Polonium was extracted from $2 \mathrm{~g}$ of dry peat powder using a sequential $\mathrm{H}_{2} \mathrm{O}_{2}-\mathrm{HNO}_{3}-\mathrm{HCl}$ digestion. To control efficiency of 
Table 1 Results of ${ }^{210} \mathrm{~Pb}$ analysis

\begin{tabular}{|c|c|c|c|c|c|c|c|}
\hline Lab nr. & $\begin{array}{c}\text { Mean } \\
\text { depth }(\mathrm{cm})\end{array}$ & $\begin{array}{c}{ }^{210} \mathrm{~Pb} \text { corrected } \\
\text { date }(\mathrm{AD})\end{array}$ & $\begin{array}{c}\text { Uncertainty } \\
(\mathrm{yr})\end{array}$ & Lab nr. & $\begin{array}{c}\text { Mean } \\
\text { depth }(\mathrm{cm})\end{array}$ & $\begin{array}{c}{ }^{210} \mathrm{~Pb} \text { corrected } \\
\text { date }(\mathrm{AD})\end{array}$ & $\begin{array}{c}\text { Uncertainty } \\
(\mathrm{yr})\end{array}$ \\
\hline $0-1$ & 0.5 & 2006 & 1 & $18-19$ & 18.5 & 1978 & 2 \\
\hline $1-2$ & 1.5 & 2005 & 2 & 19-20 & 19.5 & 1975 & 2 \\
\hline $2-3$ & 2.5 & 2004 & 2 & $20-21$ & 20.5 & 1973 & 3 \\
\hline $3-4$ & 3.5 & 2003 & 2 & $21-22$ & 21.5 & 1970 & 3 \\
\hline $4-5$ & 4.5 & 2002 & 2 & $22-23$ & 22.5 & 1966 & 3 \\
\hline $5-6$ & 5.5 & 2001 & 2 & $23-24$ & 23.5 & 1962 & 3 \\
\hline $6-7$ & 6.5 & 2000 & 2 & $24-25$ & 24.5 & 1958 & 3 \\
\hline $7-8$ & 7.5 & 1999 & 2 & $25-26$ & 25.5 & 1953 & 3 \\
\hline $8-9$ & 8.5 & 1998 & 2 & $26-27$ & 26.5 & 1946 & 3 \\
\hline $9-10$ & 9.5 & 1997 & 2 & $27-28$ & 27.5 & 1936 & 3 \\
\hline $10-11$ & 10.5 & 1996 & 2 & $28-29$ & 28.5 & 1928 & 3 \\
\hline $11-12$ & 11.5 & 1995 & 2 & $29-30$ & 29.5 & 1919 & 3 \\
\hline $12-13$ & 12.5 & 1993 & 2 & $30-31$ & 30.5 & 1911 & 3 \\
\hline $13-14$ & 13.5 & 1991 & 2 & $31-32$ & 31.5 & 1902 & 4 \\
\hline $14-15$ & 14.5 & 1988 & 2 & $32-33$ & 32.5 & 1890 & 4 \\
\hline $15-16$ & 15.5 & 1985 & 2 & $33-34$ & 33.5 & 1870 & 6 \\
\hline $16-17$ & 16.5 & 1983 & 2 & $34-35$ & 34.5 & 1824 & 8 \\
\hline $17-18$ & 17.5 & 1980 & 2 & & & & \\
\hline
\end{tabular}

deposition and alpha detection, a portion of $\mathrm{HCl}$ containing a known amount of artificial ${ }^{208}$ Po was added before evaporation and deposition on a silver disc. Efficiency of deposition up to $80 \%$ was commonly achieved.

Alpha activity was measured with a spectrometer Canberra model 7401, with a surface-barrier Si semiconductor detector. The sensitive area of the detector is $300 \mathrm{~mm}^{2}$ and its energy resolution is $20 \mathrm{keV}$. This enables a good separation of ${ }^{210} \mathrm{Po}(E=5.308$ $\mathrm{MeV})$ and ${ }^{208} \mathrm{Po}(E=5.105 \mathrm{MeV})$ peaks. As absolute activities of both isotopes are rather low, each measurement lasted two days in order to obtain sufficient accuracy. The results of the calculation were corrected for radioactive decay of ${ }^{208} \mathrm{Po}$ since the moment of its calibration, and decay of ${ }^{210} \mathrm{~Pb}$ since the moment of polonium extraction from sediments.

The Constant Rate of Supply (CRS) model (Appleby, 2001) was applied in order to build the ${ }^{210} \mathrm{~Pb}$ age model. The activity of autigenic ${ }^{210} \mathrm{~Pb}$ is assumed to be constant along the sediment column. It is determined by measurements on sediments old enough to contain no allochthonous ${ }^{210} \mathrm{~Pb}$. The activity of allochthonous lead is then calculated by subtracting the activity of autigenic lead from the total lead activity. Uncertainties were calculated using the propagation of errors technique according to ISO, Guide to the expression of uncertainty in measurement. Results are summarized in Table 1.

\section{${ }^{14} \mathrm{C}$ dating}

Macrofossils were carefully selected from eight peat samples of SL4, after soaking in $\mathrm{mQ}$ water and transfer in a Petri dish, following the protocol developed by Kilian et al. (1995) and Mauquoy et al. (2004). In this way only the parts of aboveground plants were selected for ${ }^{14} \mathrm{C}$ dating. Young carbon contamination by downward growing rootlets was therefore prevented. In the samples from Słowińskie Błota, the main macrofossils collected were Sphagnum spp. stems and opercula, Calluna vulgaris stems, Erica tetralix stems and inflorescences and Andromeda polifolia leaves (Table 2). Charcoal fragments and some seeds were also

Table 2 Description of samples chosen for ${ }^{14} \mathrm{C}$ AMS dating and results of measurements and calibration

\begin{tabular}{|c|c|c|c|c|}
\hline Lab no. & $\begin{array}{l}\text { Sample depth } \\
\quad(\mathrm{cm})\end{array}$ & $\begin{array}{l}{ }^{14} \mathrm{C} \text { age } \\
(\mathrm{BP})\end{array}$ & $95.4 \%$ age interval & Sample composition \\
\hline GdA-1097 & $34.5 \pm 0.5$ & $200 \pm 30$ & $1741-1857^{*}$ & Sphagnum spp. branches and opercula, Erica tetralix inflorescence \\
\hline GdA-1088 & $36.5 \pm 0.5$ & $95 \pm 25$ & $1683-1738$ & $\begin{array}{l}\text { Sphagnum spp. branches and opercula, Calluna vulgaris branches, } \\
\text { Erica tetralix inflorescence, seeds }\end{array}$ \\
\hline GdA-1098 & $43.5 \pm 0.5$ & $455 \pm 30$ & $1416-1480$ & $\begin{array}{l}\text { Sphagnum spp. branches and opercula, Calluna vulgaris branches and } \\
\text { leaves, Erica tetralix inflorescence, Andromeda polifolia leaves, } \\
\text { charcoal, seeds }\end{array}$ \\
\hline GdA-1099 & $52.5 \pm 0.5$ & $875 \pm 40$ & $1165-1261$ & $\begin{array}{l}\text { Sphagnum spp. branches and opercula, Calluna vulgaris branches } \\
\text { and leaves, Erica tetralix inflorescence, charcoal }\end{array}$ \\
\hline GdA-1100 & $57.5 \pm 0.5$ & $935 \pm 30$ & $1084-1176$ & $\begin{array}{l}\text { Sphagnum spp. branches and opercula, Calluna vulgaris branches and } \\
\text { leaves, charcoal }\end{array}$ \\
\hline GdA-1089 & $68.5 \pm 0.5$ & $1055 \pm 30$ & $974-1026$ & Sphagnum spp. stems \\
\hline GdA-1090 & $79.5 \pm 0.5$ & $1130 \pm 30$ & $862-956$ & Sphagnum spp. stems \\
\hline GdA-1091 & $97.5 \pm 0.5$ & $1230 \pm 30$ & 675-797 & Sphagnum spp. stems \\
\hline
\end{tabular}

* Calibrated age range obtained as a result of summarizing distribution of probability of calibrated age and ${ }^{210} \mathrm{~Pb}$-derived age, assuming Gaussian distribution for the Latter. 
Table 3 Elemental geochemistry on dry bulk samples

\begin{tabular}{|c|c|c|c|c|c|c|c|c|c|c|c|c|c|}
\hline $\begin{array}{l}\text { Mean } \\
\text { depth } \\
(\mathrm{cm})\end{array}$ & $\begin{array}{c}\text { Mean } \\
\text { density } \\
\left(\mathrm{g} / \mathrm{cm}^{3}\right)\end{array}$ & $\begin{array}{c}\text { Mean } \\
\text { acc. rate } \\
(\mathrm{cm} / \mathrm{yr})\end{array}$ & $\begin{array}{l}\text { Age } \\
\text { cal. }\end{array}$ & $\begin{array}{l}\text { Unc. } \\
\text { cal. }\end{array}$ & $\begin{array}{c}\mathrm{Cl} \\
(\mathrm{ppm})\end{array}$ & $\begin{array}{c}\mathrm{K} \\
(\mathrm{ppm})\end{array}$ & $\begin{array}{c}\mathrm{Ca} \\
(\mathrm{ppm})\end{array}$ & $\begin{array}{c}\mathrm{Ti} \\
(\mathrm{ppm})\end{array}$ & $\begin{array}{c}\mathrm{Fe} \\
(\mathrm{ppm})\end{array}$ & $\begin{array}{c}\mathrm{Br} \\
(\mathrm{ppm})\end{array}$ & $\begin{array}{c}\mathrm{Rb}^{\mathrm{a}} \\
(\mathrm{ppm})\end{array}$ & $\begin{array}{c}\mathrm{Sr} \\
(\mathrm{ppm})\end{array}$ & $\begin{array}{c}\mathrm{Zr}^{\mathrm{a}} \\
(\mathrm{ppm})\end{array}$ \\
\hline 4.5 & 0.023 & 0.830 & 2002 & 3 & 611 & 2836 & 4316 & 36 & 851 & 12.8 & 5.44 & 8.77 & D.L. \\
\hline 5.5 & 0.024 & 0.826 & 2001 & 2 & 408 & 1820 & 2628 & 32.36 & 490 & 13.1 & 4.22 & 6.47 & D.L. \\
\hline 6.5 & 0.024 & 0.973 & 2000 & 2 & 390 & 1850 & 2539 & 27.3 & 622 & 13.7 & 3.78 & 6.51 & D.L. \\
\hline 7.5 & 0.024 & 1.120 & 1999 & 2 & 452 & 1493 & 1657 & 34.9 & 574 & 12.1 & 3.37 & 5.34 & D.L. \\
\hline 9.5 & 0.03 & 0.883 & 1997 & 2 & 421 & 1237 & 1065 & 38.7 & 718 & 17.3 & 3.71 & 5.89 & D.L. \\
\hline 10.5 & 0.032 & 0.590 & 1996 & 2 & 487 & 1411 & 1113 & 69 & 1024 & 14.8 & 2.52 & 4.94 & D.L. \\
\hline 13.5 & 0.057 & 0.369 & 1991 & 2 & 455 & 1084 & 802 & 31.6 & 1521 & 21.3 & 3.22 & 8.16 & D.L. \\
\hline 16.5 & 0.056 & 0.429 & 1983 & 3 & 380 & 923 & 1209 & 62.8 & 6635 & 29.3 & 3.8 & 16 & 4.11 \\
\hline 18.5 & 0.05 & 0.358 & 1978 & 3 & 301 & 766 & 1134 & 57.7 & 6949 & 27.9 & 3.73 & 15.4 & D.L. \\
\hline 21.5 & 0.044 & 0.275 & 1970 & 3 & 328 & 659 & 1310 & 81 & 5382 & 28.92 & 2.71 & 17.5 & 3.58 \\
\hline 23.5 & 0.047 & 0.176 & 1962 & 3 & 278 & 621 & 1207 & 95.3 & 5181 & 31.3 & 3.39 & 17.7 & 4.13 \\
\hline 29.5 & 0.066 & 0.095 & 1920 & 3 & 307 & 1148 & 1024 & 272 & 2840 & 59.3 & 5.41 & 18.1 & 21.4 \\
\hline 32.5 & 0.065 & 0.029 & 1888 & 5 & 330 & 748 & 895 & 138 & 1996 & 42 & 1.88 & 12.3 & 9.32 \\
\hline 34.5 & 0.058 & 0.020 & 1820 & 41 & 205 & 615 & 772 & 155 & 2021 & 23.1 & 2.86 & 11.7 & 12.9 \\
\hline 36.5 & 0.071 & 0.022 & 1719 & 31 & 309 & 1171 & 943 & 376 & 2248 & 35.2 & 6.56 & 19.1 & 35.5 \\
\hline 38.5 & 0.116 & 0.026 & 1627 & 29 & 405 & 980 & 807 & 353 & 1634 & 45.1 & 5.59 & 17 & 35.6 \\
\hline 41.5 & 0.101 & 0.031 & 1512 & 31 & 645 & 511 & 696 & 206 & 1152 & 56.8 & 2.95 & 11.7 & 19.7 \\
\hline 43.5 & 0.141 & 0.033 & 1447 & 32 & 802 & 423 & 656 & 180 & 1139 & 67.3 & 2.38 & 10.8 & 16.1 \\
\hline 45.5 & 0.149 & 0.036 & 1387 & 35 & 881 & 258 & 708 & 148 & 1231 & 59 & 1.34 & 11.4 & 14.2 \\
\hline 47.5 & 0.126 & 0.036 & 1331 & 39 & 884 & 223 & 795 & 138 & 1057 & 60.1 & 1.55 & 13.1 & 16.4 \\
\hline 51.0 & 0.05 & 0.073 & 1234 & 46 & 625 & 130 & 853 & 56 & 1306 & 54.6 & D.L. & 11.2 & D.L. \\
\hline 52.5 & 0.048 & 0.054 & 1214 & 47 & 477 & 96.4 & 901 & 34.3 & 1183 & 37.5 & D.L. & 11.1 & D.L. \\
\hline 54.5 & 0.045 & 0.063 & 1177 & 47 & 362 & 92 & 855 & 42.5 & 1229 & 36.6 & D.L. & 12 & D.L. \\
\hline 57.5 & 0.03 & 0.071 & 1129 & 45 & 294 & 84.1 & 801 & 23.6 & 1319 & 32 & D.L. & 11.5 & D.L. \\
\hline 59.5 & 0.033 & 0.077 & 1101 & 42 & 413 & 109 & 1137 & 60.1 & 1318 & 38.9 & D.L. & 14.47 & 2.6 \\
\hline 61.5 & 0.031 & 0.089 & 1075 & 39 & 439 & 97.6 & 1260 & 38.5 & 1635 & 39.2 & D.L. & 15.3 & D.L. \\
\hline 66.5 & 0.035 & 0.103 & 1019 & 30 & 348 & 94.1 & 1007 & 23.3 & 1505 & 28.1 & D.L. & 12.6 & D.L. \\
\hline 73.5 & 0.035 & 0.126 & 957 & 36 & 433 & 95.2 & 923 & 32.5 & 880 & 30.8 & D.L. & 11.1 & D.L. \\
\hline 77.5 & 0.028 & 0.122 & 925 & 43 & 406 & 93.5 & 907 & 22.4 & 1336 & 34 & D.L. & 11.4 & D.L. \\
\hline 79.5 & 0.028 & 0.116 & 909 & 46 & 406 & 98.9 & 772 & 25.5 & 1026 & 33.7 & D.L. & 8.51 & D.L. \\
\hline 82.5 & 0.037 & 0.110 & 883 & 49 & 366 & 101 & 837 & 28.3 & 842 & 33.7 & D.L. & 8.02 & D.L. \\
\hline 84.5 & 0.04 & 0.106 & 865 & 51 & 354 & 103 & 663 & 32.5 & 735 & 35.5 & D.L. & 8.08 & D.L. \\
\hline 86.5 & 0.04 & 0.104 & 846 & 52 & 441 & 113 & 721 & 37.1 & 749 & 44.9 & D.L. & 8.52 & D.L. \\
\hline 88.5 & 0.028 & 0.101 & 827 & 54 & 438 & 104 & 689 & 30.4 & 679 & 42.3 & D.L. & 7.87 & D.L. \\
\hline 91.5 & 0.024 & 0.099 & 797 & 56 & 462 & 103 & 684 & 34.5 & 505 & 37.3 & D.L. & 8.08 & D.L. \\
\hline 95.5 & 0.031 & 0.098 & 757 & 59 & 419 & 112 & 746 & 34.9 & 688 & 37.6 & D.L. & 8.32 & D.L. \\
\hline 97.5 & 0.025 & 0.098 & 736 & 60 & 413 & 101 & 720 & 22.5 & 651 & 33.4 & D.L. & 6.97 & D.L. \\
\hline \multicolumn{5}{|c|}{ Uncertainty (\%) } & 10 & 10 & 3 & 7 & 7 & 5 & 5 & 5 & 10 \\
\hline \multicolumn{5}{|c|}{ LLD } & 30 & 2.5 & 1.5 & 0.9 & 0.9 & 0.6 & 0.8 & 1 & 2.5 \\
\hline
\end{tabular}

${ }^{a}$ D.L., measurements below detection limit.

collected when other plants were not present in sufficient quantities for ${ }^{14} \mathrm{C}$ AMS. Before measurement, samples were pre-treated using an acid-alkali-acid washing sequence in order to remove any carbonate, bacterial $\mathrm{CO}_{2}$ and humic/fulvic acids. The graphite targets were produced according to a protocol used in the Gliwice Radiocarbon Laboratory (Goslar and Czernik, 2000). ${ }^{14} \mathrm{C}$ measurements were performed at Poznan Radiocarbon Laboratory (Poland) following the protocol described by Goslar et al. (2004).

\section{X-ray fluorescence}

Forty-one samples were selected along SL4 core for XRF analysis. Samples were freeze-dried and then powdered in an automatic agate mortar (400 rpm, $1 \mathrm{~h}$ ). One gram of the resulting powder was analysed for selected elements at the Institute of Environmental Geochemistry (Heidelberg, Germany). Energy-dispersive Miniprobe Multielement Analyzer EMMA (Cheburkin and Shotyk, 1996) was used to analyse $\mathrm{Br}, \mathrm{Rb}, \mathrm{Sr}$ and $\mathrm{Zr}$ while energy dispersive XRF spectrometer TITAN (Cheburkin and Shotyk, 2005) was used to analyse minor elements $\mathrm{Cl}, \mathrm{K}, \mathrm{Ca}$ and Ti. The two analysers are calibrated with various organic international standards: coals (NIST1632b, NIST1635, SARM19 and SARM 20) and plant material (NIST 1515, NIST 1547, NIST 1575, BCR60 and BCR 62). The results, detection limits and uncertainties are given in Table 3.

\section{Plant macrofossils}

Plant macrofossil samples from SL4 were boiled with 5\% KOH and sieved (mesh diameter $125 \mu \mathrm{m}$ ). Macrofossils were scanned using a binocular microscope $(\times 10-50)$, and identified using an extensive reference collection of type material (Mauquoy and van Geel, 2007). Volume percentages were estimated for all components with the exception of seeds, Eriophorum vaginatum spindles, 


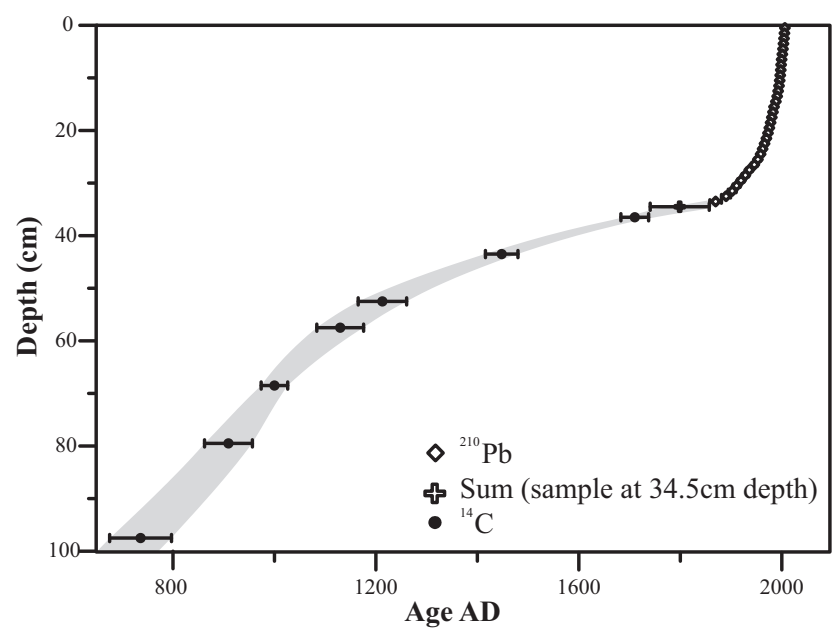

Figure 2 Age-depth model constructed on the basis of ${ }^{210} \mathrm{~Pb}$ and ${ }^{14} \mathrm{C}$ dating (see text for details). Diamonds represent results of ${ }^{210} \mathrm{~Pb}$ dating; cross represents midpoint of $95.4 \%$ age interval obtained as a result of summarizing ${ }^{210} \mathrm{~Pb}$ and ${ }^{14} \mathrm{C}$ calibrated age; circles represent midpoints of $95.4 \%$ calibrated ${ }^{14} \mathrm{C}$ age range (see Table 2). Error bars and the grey-shaded area show $95.4 \%$ confidence interval of age for dated horizons and the model respectively

Sphagnum spore capsules, Meliola ellisii (Type 14) fruit-bodies and charcoal particles, which were counted and expressed as the number $(n)$ present in each subsample. Zonation of the macrofossil diagrams was made using psimpoll 4.25 (optimal splitting by information content).

\section{Stable isotopes}

Samples for isotopic investigations were taken at each centimetre of the SL4 peat monolith. Each sample was washed in distilled water. Then one Sphagnum stem was selected from each sample using low-power microscopy. Loader et al. (2007) reported statistically significant differences between the carbon isotopic composition of bulk organic material in pendant leaves, branch leaves and stems of growing Sphagnum. Therefore all the leaves, if present, were carefully removed. Then, stems were dried in an oven at $50^{\circ} \mathrm{C}$. Because isotopic composition of carbon in bulk organic material closely follows the isotopic pattern measured in $\alpha$-cellulose and nitrocellulose (Ménot-Combes et al., 2004; Skrzypek et al., 2007), all the measurements were performed on bulk organic material of Sphagnum stems. Fragments of stems weighing about $50 \mu \mathrm{g}$ were used for each measurement. The samples were packed in tin capsules and combusted in the EuroVector EuroEA3000 elemental analyser at $1020^{\circ} \mathrm{C}$. The resulting gases were separated by the gas chromatography method and $\mathrm{CO}_{2}$ was transferred to a GV Instruments IsoPrime isotope ratio mass spectrometer. The $\delta^{13} \mathrm{C}$ values are expressed in \%o VPDB with an uncertainty equal or better than $0.22 \%$.

\section{Results}

\section{Ombrotrophy}

Low strontium values have already been used to indicate the ombrotrophy of peat deposits (eg, Shotyk et al., 2002; De Vleeschouwer et al., 2007), ie, bogs that are exclusively fed by atmospheric inputs (eg, rain, snow, fog, dust). In Słowińskie Błota, $\mathrm{Sr}$ values below $20 \mathrm{ppm}$ (Table 3) indicate the ombrotrophic nature of the entire $1 \mathrm{~m}$ peat profile. The plant macrofossils (see Figure 4) also consistently indicate the presence of acidic, nutrient-poor conditions characteristic of ombrotrophic peat bogs.

\section{Age-depth relationship}

Calibration of radiocarbon dates was undertaken using the IntCa104 calibration curve (Reimer et al., 2004) and OxCal 4.0 software (Bronk Ramsey, 1995, 2001). A priori information from the ${ }^{210} \mathrm{~Pb}$-derived ages was used in a $P$-sequence model (Bronk Ramsey, 2008). The results of calibration are summarized in Table 2.

From the base of the core to $34.5 \mathrm{~cm}$ depth, ${ }^{14} \mathrm{C}$ was used to build an age-depth model. For the sample from depth $34.5 \mathrm{~cm}$ the probability distribution of calendar ages obtained with both ${ }^{210} \mathrm{~Pb}$ and ${ }^{14} \mathrm{C}$ methods were combined, resulting in the interval AD 1741-1857. Above $34.5 \mathrm{~cm}$ the results of ${ }^{210} \mathrm{~Pb}$ dating were used.

For building the age-depth model a non-linear approach (generalized additive model, GAM) was used, as described by Heegaard et al. (2005). The calculations were performed within each period on the middle-point of the $95.4 \%$ range of calibrated age, while an uncertainty equal to the half of this range was assumed. The results of ${ }^{210} \mathrm{~Pb}$ dating are described by Gaussian distribution and in their case the 1-sigma range was used. On the depth scale, the resulting age-depth relationship provides a mean age and an age range for each slice of peat (Figure 2).

From the base (c. AD 675-800) of the core to $52.5 \mathrm{~cm}$ depth (c. $\mathrm{AD}$ 1065-1260), the mean peat accumulation rate is rather high (mean $=1 \mathrm{~mm} / \mathrm{yr}$ ). Then, the mean accumulation rate decreases towards $0.3 \mathrm{~mm} / \mathrm{yr}$ from $52.5 \mathrm{~cm}$ depth (c. AD 1065-1260) to 34.5 $\mathrm{cm}$ depth (AD 1740-1860). For the samples between 34.5 and $0 \mathrm{~cm}$ depth, the mean accumulation rate is higher, and reflects the fresh, uncompacted nature of the acrotelm peat deposits.

\section{Bulk density, Ti concentration and atmospheric soil dust flux}

The bulk density and Ti profiles record small variations from the base of the core to $50 \mathrm{~cm}$ depth (Figure 3). Then a sharp peak in bulk density occurs between 50 and $35.5 \mathrm{~cm}$ depth. Peak values in the Ti profile also occur in the same depth interval. From 30 to $20 \mathrm{~cm}$ depth, the bulk density stabilises between $0.05 \mathrm{~g} / \mathrm{cm}^{3}$ and 0.06 $\mathrm{g} / \mathrm{cm}^{3}$. However, at this depth, the Ti profile displays a second peak. Values of bulk density then decrease gradually towards the surface of the profile. Titanium concentration fluctuations have been used to indicate fluctuations in soil dust inputs to bogs (Görres, 1993; Holynska et al., 1998; Shotyk et al., 1998). These changes in soil dust inputs can be due to various causes, such as agricultural activities (Hölzer and Hölzer, 1998) or variation in natural atmospheric soil dust fluxes (Shotyk et al., 1998).

Atmospherically derived Soil Dust (ASD) can be calculated using geochemical elements such as Ti (Shotyk et al., 2002) or Sc (Shotyk et al., 2001). Since these elements are conservative, it can be assumed that their amount in 'soil dust' is similar to their amount in the upper continental crust. Using the Ti concentration in upper continental crust $(0.40 \%$, McLennan, 2001), the concentration of 'soil dust' in a peat sample can be deduced (Shotyk et al., 2001). Taking into account the bulk density and the mean accumulation rate derived from ${ }^{14} \mathrm{C}$ and ${ }^{210} \mathrm{~Pb}$ dates, ASD in a sample can be calculated (Shotyk et al., 2002).

The ASD flux for the Słowińskie Błota profile can be divided into five zones (Figure 3). From the base of the core to $50 \mathrm{~cm}$ depth, ASD values are very low, with a mean averaging $22 \mu \mathrm{g} / \mathrm{cm}^{2}$ per yr. Given the ${ }^{14} \mathrm{C}$ dates, this part of the core was deposited during the early Middle Ages. This period is followed by a period of increased ASD $\left(\right.$ mean $=156 \mu \mathrm{g} / \mathrm{cm}^{2}$ per yr) between $50 \mathrm{~cm}$ and 35 $\mathrm{cm}$ depth, spanning the eleventh to the beginning of the eighteenth centuries (late Middle Ages and early Modern Era). Then ASD reaches very high values (mean $=446 \mu \mathrm{g} / \mathrm{cm}^{2}$ per yr) between 30 and $25 \mathrm{~cm}$ depth, ie, during the first half of the twentieth century. From 24 to $13 \mathrm{~cm}$ depth, ie, during from $c$. AD 1960 to 1990, values 


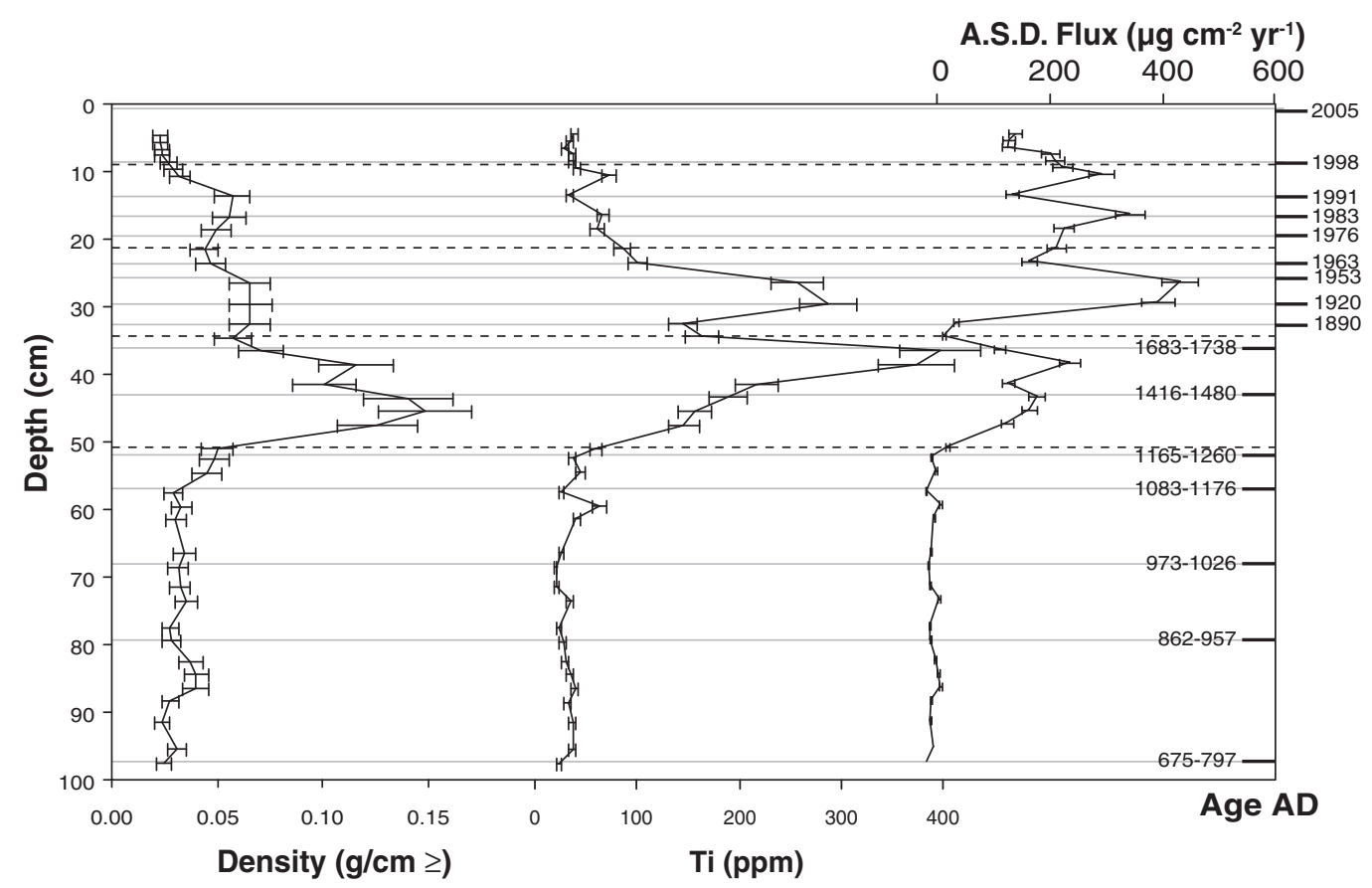

Figure 3 Density (Ti), and atmospheric soil dust flux versus depth. ${ }^{14} \mathrm{C}$ age intervals and some ${ }^{210} \mathrm{~Pb}$ reference points are also reported

average $249 \mu \mathrm{g} / \mathrm{cm}^{2}$ per yr. Then the ASD decreases drastically towards lower values (mean $=204 \mu \mathrm{g} / \mathrm{cm}^{2}$ per yr) at the surface.

\section{Detecting sources using enrichment factors}

Ti was used to calculate enrichment factors (EF) relative to the upper continental crust (UCC). Ti has been used in other studies as a conservative element to calculate EF (eg, Kempter, 1996; Shotyk et al., 2002).

Given the location of Słowińskie Błota, the main particle sources to the bog are rainwater, sea-salt sprays, ASD and anthropogenic particles from various origins (coal burning, mining and smelting). Table 4 summarizes the $\mathrm{EF}$ for each element in the five main intervals encountered in the $1 \mathrm{~m}$ core.

$\mathrm{K}, \mathrm{Rb}$ and $\mathrm{Zr}$ show very low enrichment factors. Most of these elements are therefore fed by ASD. Conversely, the higher K EF in the surface layers could be linked to plant recycling. Ca and $\mathrm{Sr}$ also record low enrichment factors, the lowest one being observed between $50 \mathrm{~cm}$ and $25 \mathrm{~cm}$ depth. In the basal (100-50 $\mathrm{cm})$ and uppermost $(25-0 \mathrm{~cm})$ part of the core, these elements record a moderate increase in enrichment factor $(\mathrm{Ca} \mathrm{EF}$ and $\mathrm{Sr}$ $\mathrm{EF}(100-50 \mathrm{~cm})=4 ; \mathrm{Ca} \mathrm{EF}$ and $\mathrm{Sr} \mathrm{EF}(10-0 \mathrm{~cm})=9$ and 2, respectively). These values may be explained by sea-salt sprays from the nearby Baltic Sea.

By contrast, $\mathrm{Cl}$ and $\mathrm{Br}$ display high enrichment factors $(7<\mathrm{Cl}$ $\mathrm{EF}<84$ and $445<\mathrm{Br} \mathrm{EF}<2906)$. These elements are strongly enriched in seawater relative to the upper continental crust, making sea-salt sprays the most likely source for $\mathrm{Cl}$ and $\mathrm{Br}$. However, $\mathrm{Cl}, \mathrm{Br}, \mathrm{Ca}$ and $\mathrm{Sr}$ cannot be used as quantitative indicators of marine aerosols inputs, although partly fed by sea-salt sprays. Indeed Shotyk (1997) showed that more than $90 \%$ of the elements supplied to the bog by marine-influenced rainwater are not retained by the peat.

\section{Plant macrofossils}

The results presented in Figure 4 and Table 5 record the main features of the four macrofossils zones. Relationships between the plant macrofossil components were explored using principal components analysis (PCA) (Figure 5). The SL4 macrofossil stratigraphy registers relatively low local water-table depths in zone SL4-1, given the abundance of Sphagnum section Acutifolia leaves, whilst charcoal fragments are sporadic and not present in significant numbers. Towards the top of the zone the samples from

Table 4 Enrichment factors calculated in the five depth intervals of the core using values from the upper continental crust (McLennan, 2001) and $\mathrm{Ti}$ as a conservative element

\begin{tabular}{|c|c|c|c|c|c|c|c|}
\hline & $\begin{array}{l}\text { Concentrations } \\
\text { in } \mathrm{UCC}(\mu \mathrm{g} / \mathrm{g})\end{array}$ & $\begin{array}{c}\text { Values/Ti } \\
\text { UCC }\end{array}$ & $\begin{array}{c}100 \mathrm{~cm}-50 \mathrm{~cm} \\
\text { E.F. (Ti) }\end{array}$ & $\begin{array}{c}50 \mathrm{~cm}-35 \mathrm{~cm} \\
\text { E.F. (Ti) }\end{array}$ & $\begin{array}{c}35 \mathrm{~cm}-25 \mathrm{~cm} \\
\text { E.F. (Ti) }\end{array}$ & $\begin{array}{c}20 \mathrm{~cm}-10 \mathrm{~cm} \\
\text { E.F. (Ti) }\end{array}$ & $\begin{array}{c}10 \mathrm{~cm}-0 \mathrm{~cm} \\
\text { E.F. (Ti) }\end{array}$ \\
\hline $\mathrm{Cl}$ & 640 & 0.16 & 84 & 20 & 7 & 41 & 82 \\
\hline $\mathrm{K}$ & 28650 & 7.15 & 0 & 0 & 1 & 2 & 7 \\
\hline $\mathrm{Ca}$ & 29450 & 7.34 & 4 & 1 & 1 & 2 & 9 \\
\hline $\mathrm{Br}$ & 1.6 & 0.0004 & 2906 & 676 & 445 & 1054 & 1050 \\
\hline $\mathrm{Rb}$ & 110 & 0.03 & $-^{\mathrm{a}}$ & 1 & 1 & 2 & 4 \\
\hline $\mathrm{Sr}$ & 316 & 0.08 & 4 & 1 & 1 & 3 & 2 \\
\hline $\mathrm{Zr}$ & 237 & 0.06 & 0 & 2 & 1 & 0 & $--^{\mathrm{a}}$ \\
\hline
\end{tabular}

\footnotetext{
${ }^{a}$ Value missing as concentrations in these intervals are below detection limits.
} 
Table 5 SL4 macrofossil zonation

\begin{tabular}{|c|c|c|}
\hline Macrofossil zone & Depth $(\mathrm{cm})$ & Main features \\
\hline SL4-4 & $15.5-2$ & $\begin{array}{l}\text { Very low presence of charcoal } \\
\text { fragments with abundant Sphagnum } \\
\text { section Acutifolia leaves. Leaves of } \\
\text { Aulacomnium palustre occur between } \\
10.5 \text { and } 2.5 \mathrm{~cm} \text { and form up to } 5 \% \text { of } \\
\text { the peat matrices }\end{array}$ \\
\hline SL4-3 & $27.5-15.5$ & $\begin{array}{l}\text { Strong reduction in the number of } \\
\text { charcoal fragments, with a large } \\
\text { increase in Sphagnum section } \\
\text { Cuspidata leaves, which record peak } \\
\text { values at } 20.5 \mathrm{~cm} \text {. Ericales rootlets } \\
\text { and Calluna vulgaris stems increase } \\
\text { between } 18.5 \text { and } 16.5 \mathrm{~cm}\end{array}$ \\
\hline SL4-2 & $45.5-27.5$ & $\begin{array}{l}\text { Abundant charcoal fragments are } \\
\text { present throughout the zone, with the } \\
\text { highest number recorded between } \\
42.5 \text { and } 40.5 \mathrm{~cm} \text {. The major components } \\
\text { of the peat matrices are Monocots } \\
\text { undifferentiated and Eriophorum } \\
\text { vaginatum epidermis and roots. High } \\
\text { values of Sphagnum section } \\
\text { Cuspidata leaves (up to } 59 \% \text { ) were } \\
\text { recorded between } 36.5 \text { and } 34.5 \mathrm{~cm} \text {. } \\
\text { Seeds of Rhynchospora alba occur at } \\
32.5 \text { and } 28.5 \mathrm{~cm}\end{array}$ \\
\hline SL4-1 & $91-45.5$ & $\begin{array}{l}\text { Abundant Sphagnum section } \\
\text { Acutifolia leaves with some } \\
\text { Eriophorum vaginatum epidermis and } \\
\text { roots. Charcoal fragments are } \\
\text { infrequent, and where present do not } \\
\text { record high values. Towards the top } \\
\text { of the zone }(52.5-46.5 \mathrm{~cm}) \text { leaves of } \\
\text { Sphagnum section Cusidata and } \\
\text { Sphagnum tenellum appear and } \\
\text { increase in abundance (maximum } \\
\text { abundance values of } 15 \text { and } 20 \% \text {, } \\
\text { respectively) }\end{array}$ \\
\hline
\end{tabular}

mid-point depths 52.5-46.5 cm (c. AD 1210 to AD 1360), record increased mire surface wetness, given the presence of Sphagnum section Cuspidata and Sphagnum tenellum leaves. In zone SL4-2 high percentage values of Sphagnum section Cuspidata and peak percentage values of Sphagnum cuspidatum (mid-point depths between 36.5 and $34.5 \mathrm{~cm}, \mathrm{AD} 1720$ to $\mathrm{AD} 1820$ ) alternate with high values of Monocots undifferentiated, Eriophorum vaginatum epidermis/spindles and the highest recorded values of charcoal fragments. This zone therefore records the highest mire surface wetness in the peat profile and additionally the greatest disturbance, given the abundant presence of macroscopic charcoal indicating the occurrence of surface peat fires (charred leaves and stems of Calluna vulgaris are present in the peat matrices in this zone). Charcoal fragments decrease markedly in zone SL4-3, whilst the disappearance of aquatic Sphagnum cuspidatum and the increased representation of Calluna vulgaris stems indicate lower local water-table depths. Local water-table depths appear to have decreased further in zone SL4-4, as Sphagnum section Acutifolia leaves return as the dominant component of the peat matrices. Fires appear to have been very infrequent in the final zone, since charcoal fragments are rare. The Eigen values of axis $1(0.598)$ and axis $2(0.209)$ represent $80.7 \%$ of the cumulative percentage variance of the species data (Figure 5). Axis 1 seems to be determined by a moisture/burning gradient, with hummock microform taxa on the

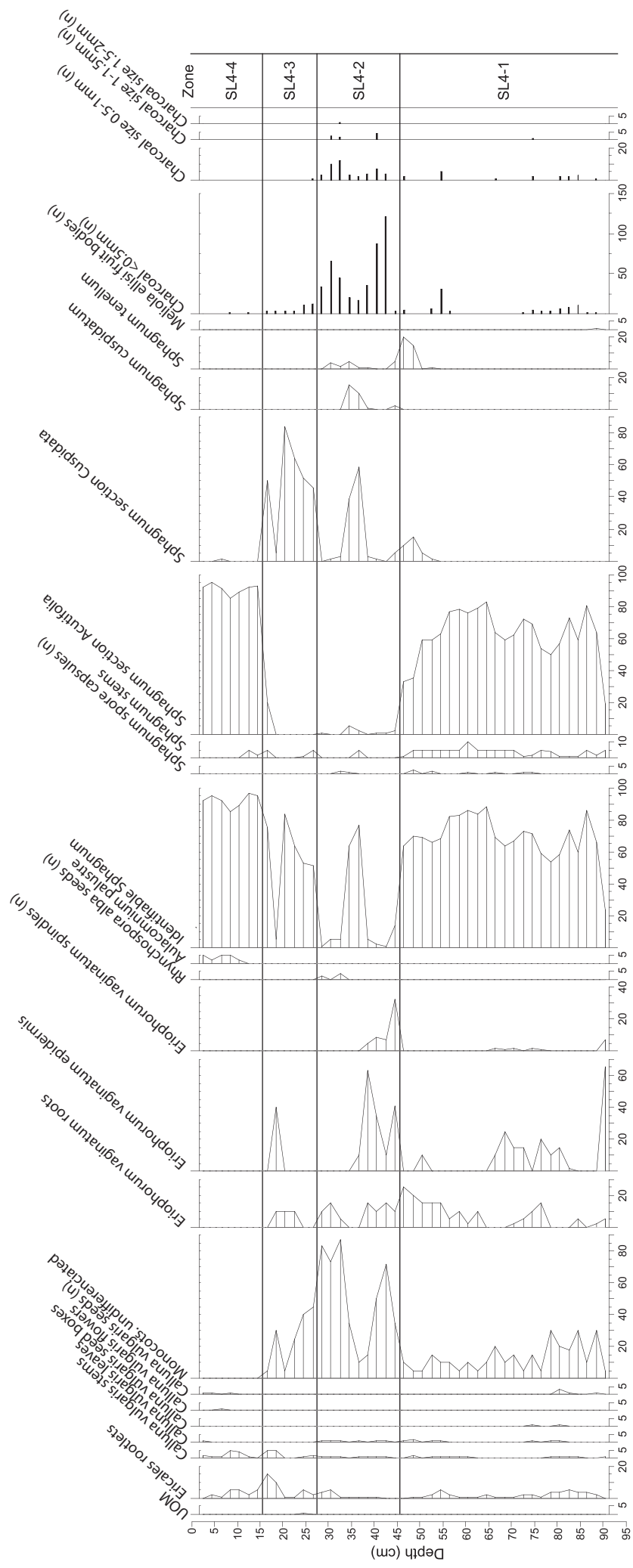

Figure 4 Percentage of plant macrofossil in SL4. Zonations made using information content in psimpoll 4.25

left (Sphagnum section Acutifolia leaves, Aulacomnium palustre and Calluna vulgaris flowers/seeds). Two groups on the right of the PCA ordination indicate hollow microform taxa (Sphagnum cuspidatum/section Cuspidata and Sphagnum tenellum) and plants (Eriophorum vaginatum and Rhynchospora alba) associated with the burning of the bog surface (Sillasoo et al., 2007). 


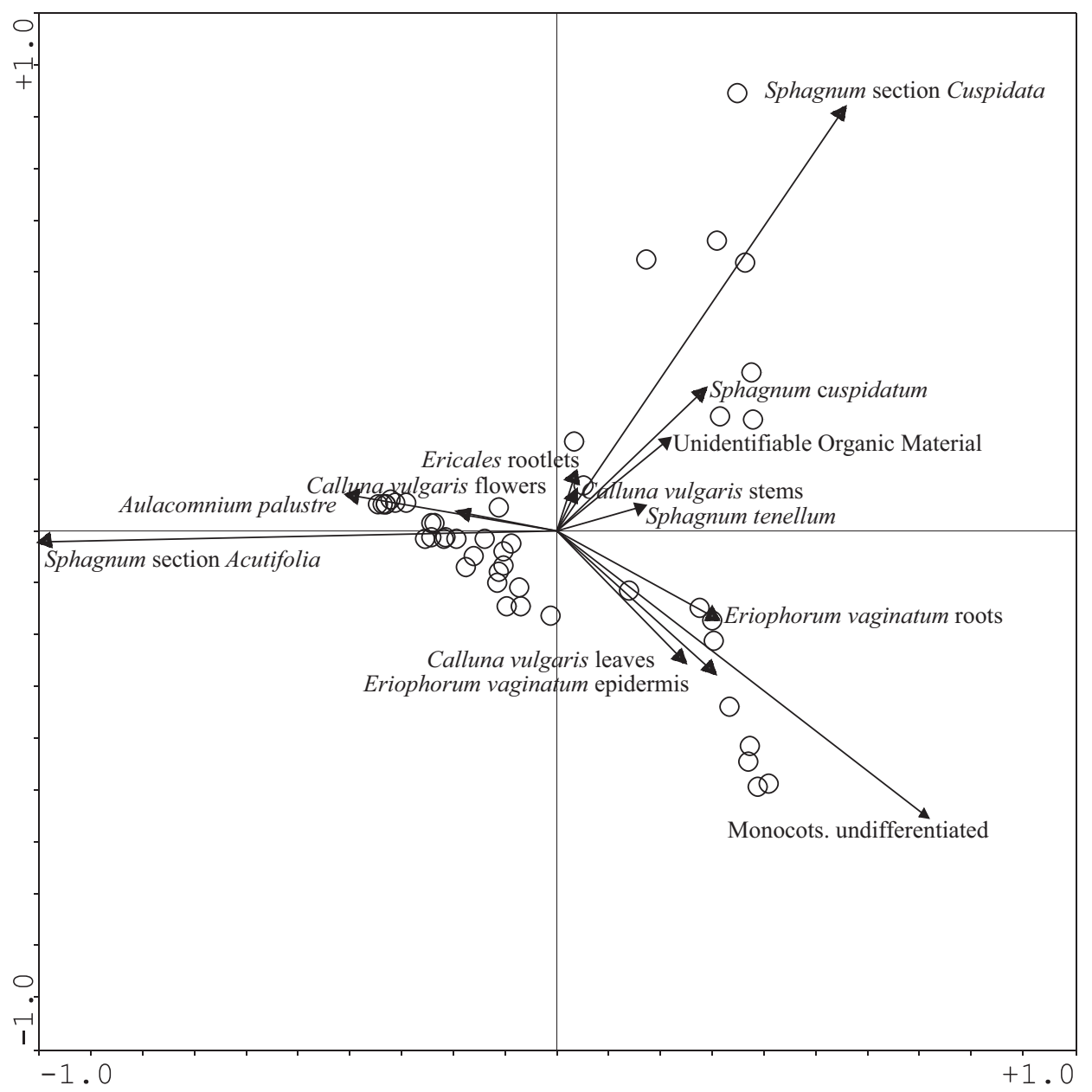

Figure 5 Principal component analysis biplot of the SL4 plant macrofossil data. The ordination was performed using CANOCO for Windows version 4.02, using the following options: focus scaling on interspecies correlations, species scores divided by standard deviation, centering/ standardization by species

\section{Stable isotopes}

The raw $\delta^{13} \mathrm{C}$ data are presented in Figure 6 and record a large spread of individual points. This scatter is due to the differences of carbon isotopic composition in different Sphagnum species (Hornibrook et al., 2000). The raw data points were therefore smoothed using a three-point running average filter. Mean values for the raw $\delta^{13} \mathrm{C}$ data up to $\mathrm{AD} 1900$ are equal to $-27.39 \%$ VPDB. The smoothed curve was zoned into four periods. The first period (AD 800-1200) is characterized by rather large fluctuations of $\delta^{13} \mathrm{C}$ oscillating below (AD 800-1000) and above (AD 1000-1200) the mean value for the whole core. During the second period from $c$. $\mathrm{AD} 1200$ to $c$. $\mathrm{AD} 1580$, the $\delta^{13} \mathrm{C}$ values first increase up to $-25.6 \%$

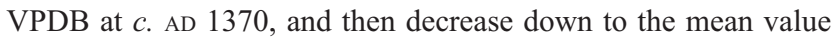
for the whole core. A similar pattern was observed for the third period from $c$. AD 1580 to $c$. AD 1850 with the maximum of $25.5 \%$ VPDB at $c$. AD 1700. During the fourth period (from $c$. AD 1850) human disturbance (exploitation of the peat) probably caused large decreases of the $\delta^{13} \mathrm{C}$ signal. Indeed, the $\delta^{13} \mathrm{C}$ value in Sphagnum organic matter depends on several factors, the most important being the amount of water stored in the hyaline cells. Models showed that a decreasing amount of water stored in the hyaline cells will increase isotopic fractionation resulting in a decrease of the $\delta^{13} \mathrm{C}$ value (Ménot-Combes et al., 2004). The successive drainage of Słowińskie Błota caused a drop of local watertable and lead to the decrease of water content in leaves, explaining the drop in the $\delta^{13} \mathrm{C}$ during this period.

\section{Discussion}

Causes of LIA deterioration in Słowińskie Błota The ASD flux profile versus depth (Figure 3 ) displays five peaks around $46 \mathrm{~cm}$ (c. AD 1370), $38 \mathrm{~cm}$ (c. AD 1650), $28 \mathrm{~cm}$ (c. AD 1930), $16.5 \mathrm{~cm} \mathrm{(c.} \mathrm{AD} \mathrm{1984)} \mathrm{and} 10.5 \mathrm{~cm}$ depth (c. AD 1996). Above $30 \mathrm{~cm}$ depth, ASD can be explained by increasing industrial activities, especially coal mining and burning, and lead smelting in Poland (eg, Strzyszcz and Magiera, 2001). However, the lower part of the ASD flux profile $(100-30 \mathrm{~cm})$ may be explained by natural changes in 'soil dust' inputs, possibly related to climatic fluctuations. When the ASD flux is plotted against time (Figure 6), the interval between $c$. AD 1200 and $\mathrm{AD} 1800$ records two ASD peaks. These occur at $46 \mathrm{~cm}$ (around c. AD 1370) and $38 \mathrm{~cm}$ (c. AD 1650) and may register LIA climatic deteriorations.

In peat bogs, LIA climatic deteriorations have been detected by Barber et al. (2000) and Mauquoy et al. (2002b). In another peat bog from North Poland, Lamentowicz et al. (2008) recorded two periods of reduced peat accumulation between $\mathrm{AD}$ 1100-1500 and AD 1650-1900, respectively. These authors linked the oldest period to the LIA, whereas they explained that in their case, the youngest period is due to both LIA and human activity (ie, peat exploitation). In their work, van der Linden and van Geel (2006) also detected Wolf and Spörer minima in a Sphagnum-bog from southernmost Sweden using combined plant macrofossil, pollen and $\mathrm{C} / \mathrm{N}$ analyses. Periods of reduced 

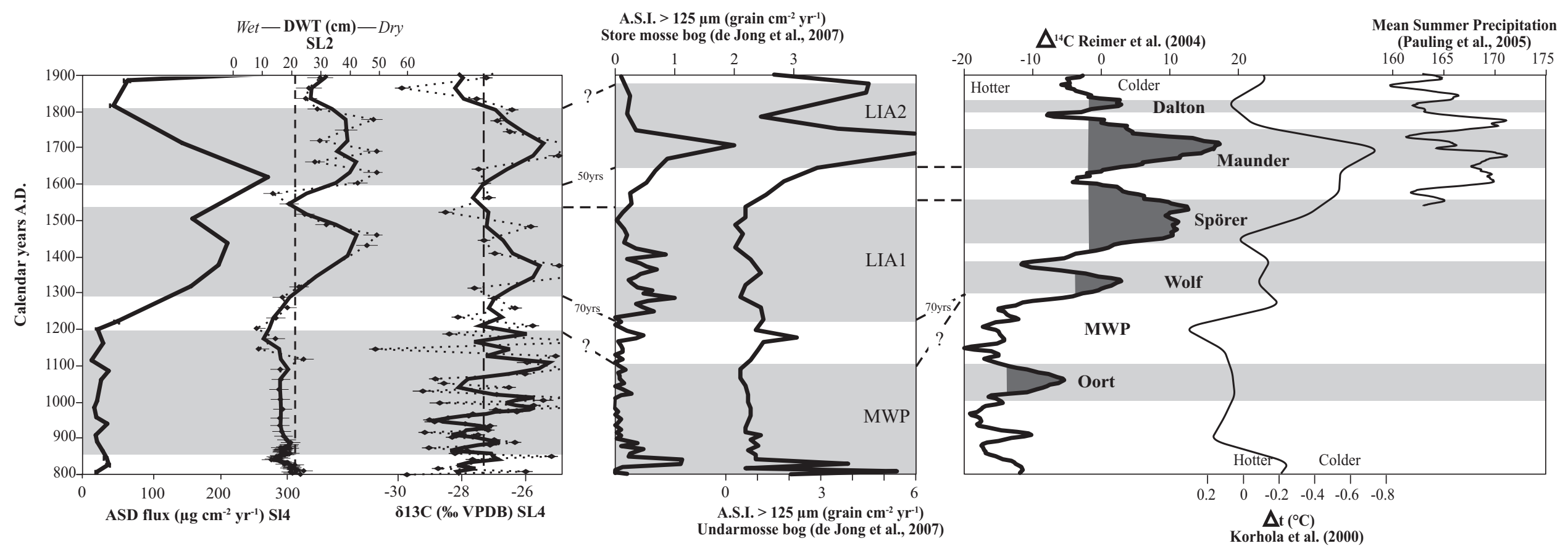

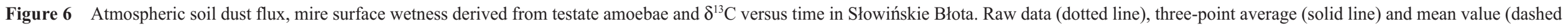

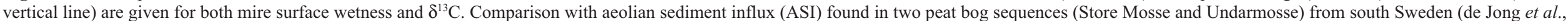
2007), $\Delta{ }^{14} \mathrm{C}$ curve (Reimer et al., 2004), temperature anomalies curve (Korhola et al., 2002) and 50-year running precipitation data presented over Northern Europe (Pauling et al., 2005) 
peat accumulation during the LIA may have been due to lower spring-summer temperatures slowing down the primary productivity of peat-forming vegetation, and cold winters causing freezing of the bog surface (Mauquoy et al., 2004). Reductions in the rate of peat accumulation have the immediate effect of increasing the relative amount of 'soil dust' found in the peat profile during the LIA. During this time span, evidence for enhanced storminess and particle transport has also been demonstrated by de Jong et al. (2007) in a raised bog from South Sweden and by Meurisse et al. (2005) in peat-dune complexes from Northern France. More specifically, Maasch et al. (2005) also suggested that the LIA could be divided into two periods: a first wet oceanic period from AD 1230 to AD 1620 followed by a dry period from AD 1700 to AD 1950. During other cold events such as the Younger Dryas stadial, it has also been demonstrated that erosion rates were enhanced, causing more resistant minerals to be weathered and transported to a peat bog, drastically increasing the ASD flux (Shotyk et al., 2002). However, during the LIA, such changes are recorded when specific conditions are encountered. For instance, de Jong et al. (2007) demonstrated clearly that changes in storm regimes in Southern Sweden and short-term changes in climatic conditions that occurred during the LIA could be recorded thanks to nearby sand dune complexes providing easily erodible material that can be transported by wind up to the peat bogs. The same specific conditions can be applied to Słowińskie Błota, which is also very near the seashore and dune complexes. Moreover, the PCA ordination of the plant macrofossil data shows a burning/disturbance gradient superimposed on to the mire surface wetness gradient. Surface fires on peat bogs can cause increased mire surface wetness (Väliranta et al., 2007), since hummock microforms can be destroyed, causing a reduction of the local microrelief and therefore promoting increased mire surface wetness (Sillasoo et al., 2007). Given this, it is possible that the increases in mire surface wetness detected with the plant macrofossil analysis are due to disturbance by fires. Pollen data from the other high-resolution study of Słowińskie Błota bog (SL2) showed the beginning of deforestation at $c$. AD 1100 (Lamentowicz et al., 2009). Consequently, increased landscape openness, surface fires and proximity to the seashore will allow soil material to be available for erosion and subsequent deposition as ASD in the mire. In other words, $c .150$ years before the onset of the LIA soil was made available for future erosion, providing an ideal source of particles to be transported by wind to the peat bog.

In Słowińskie Błota, the increase of ASD is also correlated with a shift in DWT (Figure 6), reflecting that the onset of LIA is characterized by increased storminess and dryness of the area. Moreover, the lower $\mathrm{Cl} \mathrm{EF}$ and $\mathrm{Br} \mathrm{EF}$ values between 50 and $30 \mathrm{~cm}$ depth (Table 4) may indicate a more continental climate over North Poland during this period. These results do not correspond with the initial wet shift observed by de Jong et al. (2007) at the beginning of the LIA. However, de Jong et al. (2007) also pointed out that the climatic anomalies associated with the LIA and MWP they have evidenced in their record are reflected as periods with predominantly dry or wet conditions. They noticed that these aeolian activity peaks started during the recorded hydrological transitions, regardless of the direction of these shifts. In North Poland, Lamentowicz et al. (2008) explained that the development of peat bogs in this area could be driven by westerlies during wet periods, and by more continental influence during dry periods. No more precise explanation has been found so far to explain why LIA is recorded by dry shifts in Baltic bog whereas it is recorded by wet shifts in other areas such as in Southwest Sweden. Therefore, we can conclude that in our record, the ASD peaks are found during LIA, but that in some locations, they can be accompanied by wet shifts whereas in other areas, they can be accompanied by dry shifts.

\section{Timing of the LIA in NE Europe}

The first dry shift recorded by the ASD flux in Słowińskie Błota corresponds to the dry shift found by Lamentowicz et al. (2008) in another Baltic bog between AD 1100 and AD 1500. These authors also record a second zone of climatic disturbance between AD 1650 and AD 1700-1900. They explain that this second shift starts with a transition to wetter conditions, followed by a dry period, reflecting climatic instability. They claim a possible human influence superimposed to climatic dry shifts. However, the lack of evidence for human impact until AD 1800-1850 together with the strong correlation between Słowińskie Błota bog and the peat bog studied by Lamentowicz et al. (2008) support a climate-driven environmental change in both sites between AD 1650 and AD 1800. The LIA timing found in our record fits also well with the period of decreased temperature (c. AD 1400-1800) found by Jędrysek et al. (2003) in a peat core from SW Poland, although this study is lower in resolution than our work. Our results described here are also in good agreement with the timescale found for this event in tree rings from various locations in Poland (Pazdur et al., 2007), and with results found by van der Linden and van Geel (2006), who detected climatic deteriorations during the Wolf and Spörer minima between $\mathrm{AD} 1300$ and $\mathrm{AD} 1550$ in a peat bog profile from Southern Sweden. Moreover, as in the present study, they also found a synchronous increase in bulk density during this time interval. Their bulk density values vary between 0.05 and 0.15 $\mathrm{g} / \mathrm{cm}^{3}$ during the LIA, whilst values lower than $0.05 \mathrm{~g} / \mathrm{cm}^{3}$ in other time intervals were recorded outside the LIA time interval.

In Słowińskie Błota, the ages of the high ASD peaks are highly consistent with LIA intervals recorded in both southern Swedish peat deposits (Figure 6) and lake sediments from Finland (Weckström et al., 2006; Haltia-Hovi et al., 2007), which suggests that LIA climatic deteriorations may have occurred synchroneously in NE Europe. No dust peak is recorded before AD 1300 because the early 'Medieval Warm Period' is characterized by relatively stable conditions and low wind activity (de Jong et al., 2007). When comparing our data with results from de Jong et al. (2007) and other data (Figure 6), slight age discrepancies occur between the various phases of climatic fluctuations and are linked to the various sampling resolutions and constraints associated with age-depth models (Figure 6). The uppermost ASD peak found in Słowińskie Błota may correspond to the Maunder minimum. However, because of our sampling resolution, it is also possible that this ASD encompasses the Dalton minimum. The lowermost ASD peak may record both the Wolf and Spörer minima, indifferently. Nevertheless accepting a 70-year discrepancy for the base of this zone (AD 1300 in SL4 and AD 1230 found by de Jong et al., 2007), the time span for this earlier stage of the LIA is in good agreement with results from de Jong et al. (2007). It can therefore be concluded that the transition between the various LIA minima will be approximately synchroneous in NE Europe regardless of the area.

\section{Response to precipitation and temperature changes}

A three-point running average smoothing procedure was performed on testate amoebae water-table reconstruction data $\left(\mathrm{DWT}_{\mathrm{TA}}\right.$ in Figure 6) from Lamentowicz et al. (2009) and these were then compared with the isotopic data of SL4. $\delta^{13} \mathrm{C}$ in living plant organic material is controlled by photosynthesis (Farquhar et al., 1982). Carbon isotopic fractionation between atmospheric $\mathrm{CO}_{2}$ and non-vascular plant cellulose was proposed by Figge and White (1995). Climatic factors that should be considered when analysing variations of carbon isotopic composition in non-vascular plants are: temperature, humidity and the partial pressure of $\mathrm{CO}_{2}$ (Ménot-Combes et al., 2004). However, decomposition of peat organic material may disturb the 'original' carbon isotopic composition in peat (Kracht and Gleixner, 2000). To check if it 
was possible to derive more than local climatic changes from the $\delta^{13} \mathrm{C}$ signal, our $\delta^{13} \mathrm{C}$ results were compared with the reconstructed European summer precipitation curve for the last 500 years (Pauling et al., 2005) and reconstructed temperature anomalies for Fennoscandia (Korhola et al., 2002). It seems that the isotopic data are not synchronized to reconstructed mean summer precipitation for Europe. In the present study, the factors driving the $\delta^{13} \mathrm{C}$ remain difficult to identify. The $\delta^{13} \mathrm{C}$ curve is in good agreement with the reconstructed temperature data for Fennoscandia, although time-dependent discrepancies occur. Wolf and Maunder minima are clearly recorded in the $\delta^{13} \mathrm{C}$ curve although the Spörer minimum remains unclear as for both ASD and $\mathrm{DWT}_{\mathrm{TA}}$ records. This slight delay between climatic events recorded by $\mathrm{ASD}, \mathrm{DWT}_{\mathrm{TA}}$ and $\delta^{13} \mathrm{C}$ in Słowińskie Błota and Fennoscandia suggests that during last two millennia, the temperature over the southern Baltic shore decreased a few decades later than in Northern Europe during the LIA minima. Conversely, the shift towards higher temperature during optima occurred a few decades earlier than in Northern Europe.

\section{Conclusions}

The main natural sources of major elements recorded in the $1 \mathrm{~m}$ Słowińskie Błota peat profile are 'soil dust' and sea-salt sprays, which account for the main part of $\mathrm{K}, \mathrm{Ca}, \mathrm{Zr}, \mathrm{Ti}, \mathrm{Fe}$, and $\mathrm{Cl}$ and $\mathrm{Br}$ data variability.

'Little Ice Age' climatic deteriorations have rarely been identified using ASD fluxes in European peat bogs. LIA climatic deteriorations have only been detected in specific areas where peat bogs are surrounded by easily eroded material (eg, de Jong et al., 2007). In Słowińskie Błota, the particular fact that the surrounding areas were deforested by human activities 150 years before the LIA provides a unique opportunity for soils to be extensively eroded and transported. As a result, LIA climatic changes can therefore be successfully tracked using ASD in this bog. LIA climatic deteriorations are recorded in the Słowińskie Błota bog profile between $c$. AD 1200 and $c$. AD 1800 using the ASD, plant macrofossils and $\delta^{13} \mathrm{C}$. The results are in very good agreement with other records, claiming synchroneity of the LIA over NE Europe, regardless the causes and/or consequences of the LIA. In our record, these cooler and drier periods are characterized by increased soil dust fluxes possibly related to an increase in erosion processes and an increased continentality of climate. Multiproxy data (macrofossils, testate amoebae and $\delta^{13} \mathrm{C}$ ) strongly support the ASD flux record by showing changing humidity and temperature conditions during this period.

\section{Acknowledgements}

We are grateful to Helen Kurzel (IEG, Heidelberg) for her help in with the XRF analyses of the samples, Konrad Tudyka and Agnieszka Wiszniowska for their help with the ${ }^{14} \mathrm{C}$ sample preparation, and Arkadiusz Bulak for his help with the ${ }^{210} \mathrm{~Pb}$ preparation and measurements. We also warmly thank Maarten Blaauw (Queens University, Belfast) for constructive comments on the age modelling. This work is part of a larger project 'Climatic changes in Pomerania (N Poland) during the last millennium based on multiproxy high-resolution studies' (coord. M. Lamentowicz) granted by the Polish Ministry of Science and Higher Education (Contract No.: 2P04G03228). Geochemical analyses and ${ }^{14} \mathrm{C}$ dating were granted by an individual support from the University of Liège ('classic credit' to N. Fagel) and EU-funded ATIS project ('Absolute Time Scales and Isotope Studies for Investigating Events in Earth and Human History',
MTKD-CT-2005-029642). At the time of this research, F.D. was supported by FRIA (FNRS) fellowship.

\section{References}

Anshari, G., Kershaw, A.P. and van der Kaars, S. 2001: A late Pleistocene and Holocene pollen and charcoal record from peat swamp forest, Lake Sentarum Wildlife Reserve, West Kalimantan, Indonesia. Palaeogeography, Palaeoclimatology, Palaeoecology 171, 213-28.

Appleby, P.G. 2001: Chronostratigraphic techniques in recent sediments. In Last, W.M. and Smol, J.P., editors, Tracking environmental change using lake sediments, volume 1: basin analysis, coring and chronological techniques. Springer, 171-203.

Barber, K.E., Maddy, D., Rose, N., Stevenson, A.C., Stoneman, R. and Thompson, R. 2000: Replicated proxy-climate signals over the last $2000 \mathrm{yr}$ from two distant UK peat bogs: new evidence for regional palaeoclimate teleconnections. Quaternary Science Reviews 19, 481-87.

Barber, K.E., Chambers, F.M. and Maddy, D. 2003: Holocene palaeoclimates from peat stratigraphy: macrofossil proxy climate records from three oceanic raised bogs in England and Ireland. Quaternary Science Reviews 22, 521-39.

Bibler, C.J., Marshall, J.S and Pilcher, R.C. 1998: Status of worldwide coal mine methane emissions and use. International Journal of Coal Geology 35, 283-310.

Blass, A., Bigler, C., Grosjean, M. and Sturm, M. 2007: Decadalscale autumn temperature reconstruction back to AD 1580 inferred from the varved sediments of Lake Silvaplana (southeastern Swiss Alps). Quaternary Research 68, 184-95.

Bronk Ramsey, C. 1995: Radiocarbon calibration and analysis of stratigraphy: the OxCal program. Radiocarbon 37, 425-30.

_ 2001: Development of the radiocarbon calibration program OxCal. Radiocarbon 43, 355-63.

2008: Deposition models for chronological records. Quaternary Science Reviews 27, 42-60.

Cheburkin, A.K. and Shotyk, W. 1996: An energy-dispersive miniprobe multielement analyser (EMMA) for direct analyses of $\mathrm{Pb}$ and other trace elements in peats. Fresenius Journal of Analytical Chemistry 354, 688-91.

2005: Energy-dispersive XRF spectrometer for Ti determination (TITAN). X-Ray Spectrometry 34, 69-72.

Dahl-Jensen, D., Mosegaard, K., Gundestrup, N., Clow, G.D., Johnsen, S.J., Hansen, A.W. and Balling, N. 1998: Past temperatures directly from the Greenland Ice Sheet. Science 282, 268-71.

Davis, B.A.S., Brewer, S., Stevenson, A.C. and Guiot, J. 2003: The temperature of Europe during the Holocene reconstructed from pollen data. Quaternary Science Reviews 22, 1701-16.

de Jong, R., Schoning, K. and Björck, S. 2007: Increased aeolian activity during climatic regime shifts as recorded in a raised bog in south-west Sweden during the past 1700 years. Climate of the Past Discussions 3, 383-408.

De Vleeschouwer, F., Gérard, L., Goormaghtigh, C., Mattielli, N., Le Roux, G. and Fagel, N. 2007: Last two millennia atmospheric lead and heavy metals inputs in a Belgian peat bog: regional to global human inpacts. The Science of the Total Environment 377, 297-310. Farquhar, G.D., O' Leary, M.H. and Berry, J.A. 1982: On the relationship between carbon isotope discrimination and photosynthesis. Australian Journal of Plant Physiology 9, 121-37.

Figge, R.A. and White, J.W.C. 1995: A high resolution Holocene and Late Glacial atmospheric $\mathrm{CO}_{2}$ record: variability tied to changes in thermohaline circulation. Global Biogeochemical Cycles 9, 391-405. Finsinger, W., Tinner, W., van der Knaap, W.O. and Ammann, B. 2006: The expansion of hazel (Corylus avellana L.) in the southern Alps: a key for understanding its early Holocene history in Europe? Quaternary Science Reviews 25, 612-31.

Görres, M., 1993: The Pb, Br, and Ti content in peat bogs as indicator for recent and past depositions. Naturwissenschaften 80, 333-35. Goslar, T. and Czernik, J. 2000: Sample preparation in the Gliwice Radiocarbon Laboratory for AMS ${ }^{14} \mathrm{C}$ dating of sediments. Geochronometria 18, 1-8. 
Goslar, T., Czernik, J. and Goslar, E. 2004: Energy ${ }^{14} \mathrm{C}$ AMS in Poznan Radiocarbon Laboratory, Poland. Nuclear Instruments and Methods in Physics Research B 223-224, 5-11.

Görres, M. 1991: The Pb, Br, and Ti content in peat bogs as indicator for recent and past depositions. Naturwissenschaften 80, 333-35.

Haltia-Hovi, E., Saarinen, T. and Kukkonen, M. 2007: A 2000-year record of solar forcing on varved lake sediment in eastern Finland. Quaternary Science Reviews 26, 678-89.

Heegaard, E., Birks, H.J.B. and Telford, R.J. 2005: Relationships between calibrated ages and depth in stratigraphical sequences: an estimation procedure by mixed-effect regression. The Holocene 15, 612-18.

Herbichowa, M. 1998: Ekologiczne studium rozwoju torfowisk wysokich właściwych na przykładzie wybranych obiektów z środkowej czści Pobrzeża Bałtyckiego. Wydawnictwo Uniwersytetu Gdańskiego, Gdańsk, 188 pp. In Polish.

Holynska, B., Ostrachowicz, B., Ostrachowicz, J., Samek, L., Wachniew, P. and Obidowicz, A. 1998: Characterisation of 210Pb dated peat core by various x-ray fluorescence techniques. Science of the Total Environment 218, 239-48.

Hölzer, A. and Hölzer, A. 1998: Silicon and titanium in peat profiles as indicators of human impacts. The Holocene 8, 685-96.

Hornibrook, E.R.C., Longstaffe, F.J., Fyfe, W.S. and Bloom, Y. 2000: Carbon-isotope ratios and carbon, nitrogen and sulfur abundances in flora and soil organic matter from a temperate-zone bog and marsh. Geochemical Journal 34, 237-45.

Jędrysek, M.O., Krępiec, M., Skrzypek, G. and Kałużny, A. 2003: Air-pollution effect and palaeotemperature scale versus d13C records in tree rings and in peat core (Southern Poland). Water, Air, and Soil Pollution 145, 359-75.

Kempter, H. 1996: Der Verlauf des anthropogenen Elementeintrags in Regenwassermoore des westlichen Mitteleuropas während des jüngeren Holozäns. Paläoklimaforschung 26, 309.

Kilian, M.R., van der Plicht, J. and Van Geel, B. 1995: Dating raised bogs: new aspects of AMS ${ }^{14} \mathrm{C}$ wiggle matching, a reservoir effect and climatic change. Quaternary Science Reviews 14, 959-66. Korhola, A., Vasco, K., Toivonen, H.T.T. and Olander, H. 2002: Holocene temperature changes in northern Fennoscandia reconstructed from chironomids using Bayesian modelling. Quaternary Science Reviews 21, 1841-60.

Kracht, O., and Gleixner, G. 2000: Istotopic analysis of pyrolysis products from sphagnum peat and dissolved organic matter from peat. Organic Geochemistry 31, 645-54.

Kulczyński, S. 1949: Peat bogs of Polesie. Mémoires de l'Académie Polonaise des Sciences et des Lettres. Bulletin des Sciences Naturelles, B. Sco. Nat. 15, 356 pp.

Kylander, M.E., Weiss, D., Martinez-Cortízas, A., Spiro, B., Sanchez, R. and Coles, B. 2005: Refining the pre-industrial atmospheric $\mathrm{Pb}$ isotope evolution curve in Europe using and 8000 year old peat core from NW Spain. Earth and Planetary Science Letters 240, 467-85.

Kylander, M.E., Muller, J., Wust, R.A.J., Gallagher, K., GarciaSanchez, R., Coles, B.J. and Weiss, D.J. 2007: Rare earth element and $\mathrm{Pb}$ isotope variations in a $52 \mathrm{kyr}$ peat core from Lynch's Crater (NE Queensland, Australia): proxy development and application to paleoclimate in the Southern Hemisphere. Geochimica et Cosmochimica Acta 71, 942-60.

Lamentowicz, M., Cedro, A., Miotk-Szpiganowicz, G., Mitchell, E.A.D., Pawlyta, J. and Goslar, T. 2008: Last millennium palaeoenvironmental changes from a Baltic bog (Poland) inferred from stable isotopes, pollen, plant macrofossils and testate amoebae. Palaeogeography, Palaeoclimatology, Palaeoecology 265, 93-106.

Lamentowicz, M., Milecka, K., Galka, M., Cedro, A., Pawlyta, J., Piotrowska, N., Lamentowicz, L. and van der Knaap, W.O. 2009: Climate- and human-induced hydrological change since AD 800 in an ombrotrophic mire in Pomerania (N Poland) tracked by testate amoebae, macro-fossils, pollen, and tree-rings of pine. Boreas DOI 10.1111/j.1502-3885.2008.00047.x.

Latałowa, M. and Pedziszewska, A. 2003: Zbiorowiska leśne z udziałem grabu (Carpinus betulus) i buka (Fagus sylvatica) na Wysoczyźnie Gdańskiej w późnym Holocenie. Wstę pne wyniki badań. In Gołębiewski, R., editor, Ewolucja pojezierzy i pobrzeży południowobałtyckich. Fundacja Rozwoju Uniwesytetu Gdańskiego, 95-100. In Polish

Loader, N.J., McCarroll, D., van der Knaap, W.O., Robertson, I. and Gagen, M. 2007: Characterizing carbon isotopic variability in Sphagnum. The Holocene 17, 403-10.

Lukashev, K.I., Kobalev, V.A. and Zhukhovitskaya, A.L. 1974: Forms of aluminium and silicon in peat of Belorussia. Doklady Akademii Nauk SSSR 218, 681-84.

Maasch, K.A., Mayewski, P.A., Rohling, E.J., Stager, J.C., Karlen, W., Meeker, L.D. and Meyerson, E.A. 2005: A 2000-year context for modern climate change. Geografiska annaler. Series A: Physical Geography 87, 7-15.

Mauquoy, D. and van Geel, B. 2007: Mire and peat macros. In Elias, S.A., editor, Encyclopedia of Quaternary science, volume 3. Elsevier, 2315-36.

Mauquoy, D., Engelkes, T., Groot, M.H.M., Markesteijn, F., Oudejans, M.G., van der Plicht, J. and van Geel, B. 2002a: Highresolution records of late-Holocene climate change and carbon accumulation in two north-west European ombrotrophic peat bogs. Palaeogeography, Palaeoclimatology, Palaeoecology 186, 275-310.

Mauquoy, D., van Geel, B., Blaauw, M. and van der Plicht, J. 2002b: Evidence from northwest European bogs shows 'Little Ice Age' climatic changes driven by variations in solar activity. The Holocene 12, 1-6.

Mauquoy, D., van Geel, B., Blaauw, M., Speranza, A. and van der Plicht, J. 2004: Changes in solar activity and Holocene climatic shifts derived from ${ }^{14} \mathrm{C}$ wiggle-match dated peat deposits. The Holocene 14 , $45-52$.

McLennan, T. 2001: Relationships between the trace element composition of sedimentary rocks and upper continental crust. Geochemistry, Geophysics and Geosystems 2, 2000GC000109.

Ménot-Combes, G., Combes, P.P. and Burns, S.J. 2004: Climatic information from $\delta^{13} \mathrm{C}$ in plants by combining statistical and mechanistic approaches. The Holocene 14, 931-39.

Meurisse, M., Van Vliet-Lanoé, B., Talon, B. and Recourt, P. 2005: Complexes dunaires et tourbeux holocènes du littoral du Nord de la France. Comptes Rendus Geosciences 337, 675-84. In French.

Mihaljevic, M., Zuna, M., Ettler, V., Sebek, O., Strnad, L. and Golias, V. 2006: Lead fluxes, isotopic and concentration profiles in a peat deposit near a lead smelter (Pribram, Czech Republic). The Science of The Total Environment 372, 334-44.

Mukai, H., Machida, T., Tanaka, A., Vera, Y.P. and Uematsu, M. 2001: Lead isotope ratios in the urban air of eastern and central Russia. Atmospheric Environment 35, 2783-93.

Novak, M., Emmanuel, S., Vile, M.A., Erel, Y., Véron, A., Paces, T., Wieder, R.K., Vanecek, M., Stepanova, M., Brizova, E. and Hovorka, J. 2003: Origin of lead in eight Central European peat bogs determined from isotope ratios, strengths, and operation times of regional pollution sources. Environmental Science and Technology 37, 437-45.

O'Brien, S.R., Mayewski, P.A., Meeker, L.D., Meese, D.A., Twickler, M.S. and Whitlow, S.I. 1995: Complexity of Holocene climate as reconstructed from a Greenland ice core. Science 270, 1962-64. Osvald, H. 1923: Die Vegetation des Hochmoores Komosse. Svenska växtsociologiska sällskapets handlingar, 1. In German.

1925: Die Hochmore Europas. Veröffentlichungen des Geobotanischen Institutes der Technische Hochschule Stiftung Rübel in Zürich 3, 707-23. In German.

Otluszewski, W. 1948: Badania pyłkowe nad torfowiskami dolnej Łeby. Badania Fizjograficzne nad Polska Zachodnia 1, 97-128.

Otłuszewski, W. and Borówko, Z. 1954: Analiza pyłkowa torfowiska 'Bielawskie Błota'. In Czubiński, Z., editor, Bielawskie Błota ginące torfowisko atlantyckie Pomorza. Ochrona Przyrody 22, 140-52. In Polish.

Pauling, A., Luterbacher, J., Casty, C. and Wanner, H. 2005: Five hundred years of gridded high-resolution precipitation reconstructions over Europe and the connection to large-scale circulation. Climate Dynamics 26, 387-405.

Pazdur, A., Nakamura, T., Pawelczyk, S., Pawlyta, J., Piotrowska, N., Rakowski, A., Sensula, B. and Szczepanek, M. 2007: Carbon isotopes in tree rings: climate and the Suess effect interferences in the last 400 years. Radiocarbon $49,775-88$. 
Reimer, P.J., Baillie, M.G.L., Bard, E., Bayliss, A., Beck, J.W., Bertrand, C., Blackwell, P.G., Buck, C.E., Burr, G., Cutler, K.B., Damon, P.E., Edwards, R.L., Fairbanks, R.G., Friedrich, M., Guilderson, T.P., Hughen, K.A., Kromer, B., McCormac, F.G., Manning, S., Bronk Ramsey, C., Reimer, R.W., Remmele, S., Southon, J.R., Stuiver, M., Talamo, S., Taylor, F.W., van der Plicht, J. and Weyhenmeyer, C.E. 2004: IntCal04 terrestrial radiocarbon age calibration, 26-0 ka BP. Radiocarbon 46, 1029-58.

Shotyk, W. 1997: Atmospheric deposition and mass balance of major and trace elements in two oceanic peat bog profiles, northern Scotland and the Shetland Islands. Chemical Geology 138, 55-72.

Shotyk, W., Weiss, D., Appleby, P.G., Cheburkin, A.K., Frei, R., Gloor, M., Kramers, J.D., Reese, S. and van der Knaap, W.O. 1998: History of atmospheric lead deposition since $12,370{ }^{14} \mathrm{C}$ yr BP from a peat bog, Jura mountains, Switzerland. Science 281, 1635-40. Shotyk, W., Weiss, D., Kramers, J.D., Frei, R., Cheburkin, A.K., Gloor, M. and Reese, S. 2001: Geochemistry of the peat bog at Etang de la Gruère, Jura Mountains, Switzerland, and its record of atmospheric $\mathrm{Pb}$ and lithogenic trace metals ( $\mathrm{Sc}, \mathrm{Ti}, \mathrm{Y}, \mathrm{Zr}$, and $\mathrm{REE}$ ) since 12,370 14C yr BP. Geochimica et Cosmochimica Acta, 65, 2337-60. Shotyk, W., Krachler, M., Martinez-Cortizas, A., Cheburkin, A.K. and Emons, H. 2002: A peat bog record of natural, pre-anthropogenic enrichments of trace elements in atmospheric aerosols since 12370 $14 \mathrm{C}$ yr BP, and their variation with Holocene climate change. Earth and Planetary Science Letters 199, 21-37.

Sillasoo, U., Mauquoy, D., Blundell, A., Charman, D., Blaauw, M., Daniell, J.G.R., Toms, P., Newberry, J., Chambers, F.M. and Karofeld, E. 2007: Peat multi-proxy data from Männikjärve bog as indicators of Late Holocene climate changes in Estonia. Boreas 36, $20-37$. Skrzypek, G., Kaluzny, A. and Jedrysek, M.O. 2007: Carbon stable isotope analyses of mosses - comparisons of bulk organic matter and extracted nitrocellulose. Journal of the American Society for Mass Spectrometry 18, 1453-58.

Strzyszcz, Z. and Magiera, T. 2001: Record of industrial pollution in Polish ombrotrophic peat bogs. Physics and Chemistry of the Earth (A) 26, 859-66.
Stuiver, M. and Braziunas, T.F. 1993: Sun, ocean, climate and atmospheric ${ }^{14} \mathrm{CO}_{2}$ : an evaluation of causal and spectral relationships. The Holocene 3, 289-305.

Syrovetnik, K., Malmstrom, M.E. and Neretnieks, I. 2007: Accumulation of heavy metals in the Oostriku peat bog, Estonia: determination of binding processes by means of sequential leaching. Environmental Pollution 147, 291-300.

Szafrański, F. 1961: Polodowcowa historia lasów obszaru na północ od Wysoczyzny Staniszewskiej. Badania Fizjograficzne nad Polską Zachodnia 8, 91-131. In Polish.

Twardowska, I., Kyziol, J., Goldrath, T. and Avnimelech, Y. 1999: Adsorption of zinc onto peat from peatlands of Poland and Israël. Journal of Geochemical Exploration 66, 387-405.

Väliranta, M., Korhola, A., Seppä, H., Tuittila, E., SarmajaKorjonen, K., Laine, J. and Alm, J. 2007: High-resolution reconstruction of wetness dynamics in a southern boreal raised bog, Finland, during the late Holocene: a quantitative approach. The Holocene 17, 1093-107.

van der Linden, M. and van Geel, B. 2006: Late Holocene climate change and human impact recorded in a south Swedish ombrotrophic peat bog. Palaeogeography, Palaeoclimatology, Palaeoecology 240, 649-67. van Geel, B., Raspopov, O.M., Renssen, H., van der Plicht, J., Dergachev, V.A. and Meijer, H.A.J. 1999: The role of solar forcing upon climate change. Quaternary Science Reviews 18, 331-38.

Vile, M.A., Wieder, R.K. and Novak, M. 2000: 200 years of Pb deposition throughout the Czech Republic: patterns and sources. Environmental Science and Technology 34, 12-21.

Wardenaar, E.P.C. 1986: A new hand tool for cutting peat profiles. Canadian Journal of Botany 65, 1772-73.

Weckström, J., Korhola, A., Erästö, P. and Holmström, L. 2006: Temperature patterns over the past eight centuries in Northern Fennoscandia inferred from sedimentary diatoms. Quaternary Research 66, 78-86.

Wodziczko, A. and Thomaschewski, M. 1932: Staniszewskie Błoto na Kaszubczyźnie. Acta Societatis Botanicorum Poloniae 9, 1-10. In Polish. 